\title{
Synthesis, spectroscopic studies and biological evaluation of acridine derivatives: the role of aggregation on the photodynamic efficiency
}

\author{
Carles Felip-León a , Olga Martínez-Arroyo ${ }^{\text {a,b }}$, Santiago Díaz-Oltra ${ }^{\text {a,c }}$, Juan F. Miravet a , Nadezda \\ Apostolova $^{\text {b,* }}$ and Francisco Galindo ${ }^{\text {a,* }}$ \\ ${ }^{a}$ Universitat Jaume I, Departamento de Química Inorgánica y Orgánica, Avda. Sos Baynat s/n, 12071, Castellón, Spain \\ ${ }^{b}$ Universitat de València, Departamento de Farmacología, Avda. Blasco Ibañez n.15-17, 46010, Valencia, Spain \\ ${ }^{c}$ Universitat Jaume I, Departamento de Educación, Avda. Sos Baynat s/n, 12071, Castellón, Spain
}

ARTICLE INFO

ABSTRACT

Article history:

Received

Revised

Accepted

Available online

\section{Keywords:}

Self-aggregation

Organic nanoparticles

9-Amidoacridine

Photodynamic therapy

Singlet oxygen

\begin{abstract}
Two new photoactive compounds ( $\mathbf{1}$ and $\mathbf{2}$ ) derived from the 9-amidoacridine chromophore have been synthesized and fully characterized. Their abilities to produce singlet oxygen upon irradiation have been compared. The synthesized compounds show very different self-aggregating properties since only 1 present a strong tendency to aggregate in water. Biological assays were conducted with two cell types: hepatoma cells (Hep3B) and human umbilical vein endothelial cells (HUVEC). Photodynamic therapy (PDT) studies carried out with Hep3B showed that nonaggregating compound $\mathbf{2}$ showed photoxicity, ascribed to the production of singlet oxygen, being aggregating compound $\mathbf{1}$ inactive. On the other hand suspensions of $\mathbf{1}$, characterized as nano-sized aggregates, have notable antiproliferative activity towards this cell line.
\end{abstract}

2017 Elsevier Ltd. All rights reserved.
Acridine derivatives are well known biologically active compounds, widely used, for instance, as topical antibacterial and antiparasitic agents. ${ }^{1}$ They have been used also as anticancer agents since the planar structure of this chromophore permits the intercalation into the major groove of DNA and hence disruption of the replication process. ${ }^{2}$ Further understanding of their molecular mode of action showed that this biological effect is not only due to their intercalating ability but also can be explained by targeting of over expressed biomolecules in tumoral cells, such as telomerase, protein kinase and topoisomerases I and II. $^{3}$ An abundant collection of acridine-based antiproliferative compounds can be found in the literature, with plethora of structural variants designed to enhance not only their binding abilities at the site of action but also the membrane crossing features and transportation properties of the molecules through the cellular millieu. ${ }^{4}$ For example, Delcros et al. have described a series of 9-substituted aminoacridines and amidoacridines linked to polyamine chains capable to inhibit the growth of $\mathrm{L} 1210$ and $\mathrm{CHO}$ cells with $\mathrm{IC}_{50}$ values in the micromolar range. ${ }^{5}$ One strategy followed to enhance the DNA binding efficiency is the introduction of a second acridine moiety in the structure, which improves the stacking to the nucleic acids hence potentiates the biological effect. ${ }^{6}$ Apart from applications in oncology, acridines have also utility in other therapeutic fields, for instance as antimalarials ${ }^{7}$ and cholinesterase inhibitors for Alzheimer's disease therapy. ${ }^{8}$

In parallel with this conventional approach there is another therapeutic strategy also using acridine-derived compounds and light to inhibit the proliferation of cancerous cells ${ }^{9}$ and also to kill microorganisms. ${ }^{10}$ Photodynamic therapy (PDT) is a clinical tool that uses a photosensitizer in combination with visible or UV light to produce cytotoxic reactive oxygen species (ROS) including superoxide anion $\left(\mathrm{O}_{2}{ }^{-}\right)$and singlet oxygen $\left({ }^{1} \mathrm{O}_{2}\right)$. Numerous types of compounds have been employed so far for the generation of singlet oxygen, not only for photobiological applications, ${ }^{11,12}$ but also for synthetic purposes. ${ }^{13}$

The use of acridines in PDT dates back to the very origin of this discipline $^{14}$ and currently there is a renewed interest in the development of acridine derivatives for photodynamic applications. In principle, acridine chromophore is an excellent candidate to develop a bioactive photosentitizer, taking into account the very efficient population of the triplet excited state upon irradiation. ${ }^{15}$ Energy transfer to molecular triplet oxygen give rise to very high yields of ${ }^{1} \mathrm{O}_{2}\left(\Phi_{\Delta}\right)$ both in polar and apolar medium. For instance, Ogilby et al. ${ }^{16}$ have reported $\Phi_{\Delta}$ (benzene) $=0.84$ and $\Phi_{\Delta}$ (acetonitrile) $=0.97$. However, compared to the number of acridine derived compounds reported as DNA binding

\footnotetext{
* Corresponding author. F. G. Tel.: +34-964728236; fax: +34-964728214; e-mail: francisco.galindo@uji.es

* Corresponding author. N. A. Tel.: +34-963983767; fax: +34-963983879; e-mail: nadezda.apostolova@uv.es
} 
agents, the number of PDT active compounds based on this chromophore is relatively low. The aim of this study is to compare the ability of two new 9-amidoacridine compounds ( $\mathbf{1}$ and $\mathbf{2}$ in Figure 1) to generate singlet oxygen upon irradiation. The hypothesis of this work is that the superstructure adopted by the photosensitizing molecules affects dramatically to their photobiological efficiency, in such a way that aggregation can favour deactivation pathways of the excited state, leading to quenching of the photosensitizer (like molecule 1) and hence their inactivation as PDT agents. In this regard, a simpler structure (like molecule 2) avoiding this aggregation phenomenon would be more favourable for the photogeneration of singlet oxygen in aqueous medium, and then their use for clinical application more recommendable.

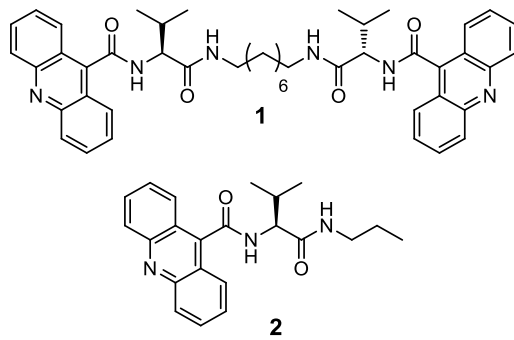

Figure 1. Synthesized compounds based on the 9-amidoacridine chromphore.

Compounds $\mathbf{1}$ and $\mathbf{2}$ were synthesized coupling carbobenzyloxy-L-valine with the corresponding amine or diamine, as depicted in Scheme 1, followed by deprotection of the $\mathrm{Cbz}$ group and reaction with acridine-9-carbonyl chloride. Compounds were purified by subsequent filtration and washing steps and were fully characterized by means of HRMS, ${ }^{1} \mathrm{H}$ and ${ }^{13} \mathrm{C}$ NMR spectroscopy (see supporting information).

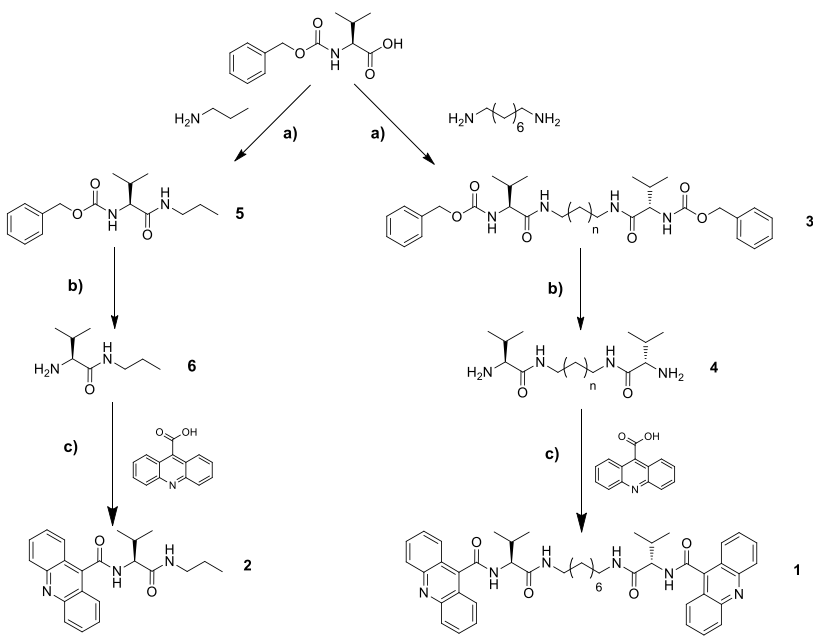

Scheme 1. Synthetic route for compounds 1 and 2 a) THF, Et ${ }_{3} \mathrm{~N} \mathrm{ClCOOEt,}$ r.t., $12 \mathrm{~h}$ b) $\mathrm{CH}_{3} \mathrm{OH}, \mathrm{Pd} / \mathrm{C} \mathrm{H}_{2}$, r.t., 6 h c) for acridine-9-carboxylic acid activation: $\mathrm{CH}_{2} \mathrm{Cl}_{2}$, Oxalyl chloride, $\mathrm{DMF}$ (cat). For activated acid and amine coupling reaction: $\mathrm{THF}, \mathrm{Et}_{3} \mathrm{~N}, 16 \mathrm{~h}$.

In acetonitrile, compounds $\mathbf{1}$ and $\mathbf{2}$ show the typical absorption of the acridine chromophore at $360 \mathrm{~nm}$, displaying optical features appropriate for UVA excitation and weak fluorescence at $419 \mathrm{~nm}$ (Figure 2). ${ }^{17}$ In a polar solvent such as water, absorption maximum undergoes opposed shifts ( $365 \mathrm{~nm}$ for 1 and $357 \mathrm{~nm}$ for 2) and fluorescence emission batochromic shifts $(439 \mathrm{~nm}$ for $\mathbf{1}$ and 435 $\mathrm{nm}$ for 2). The emission quantum yield in water is notably different: very low for compound $\mathbf{1}$ and moderate for the bisacridine derivative $\mathbf{2}$. Summarized photophysical properties of the synthesized compounds are shown in table 1 .

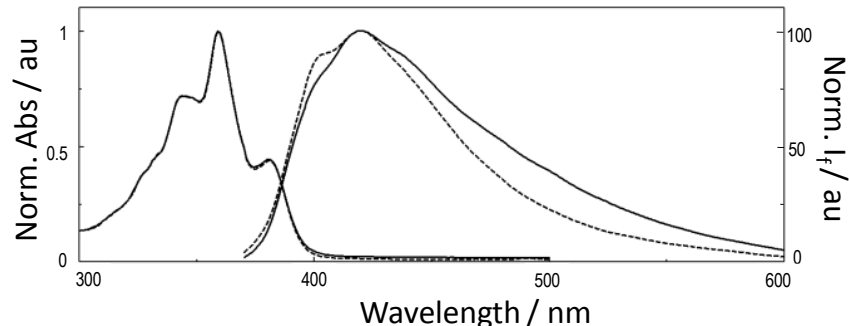

Figure 2. Absorption and emission spectra of synthesized compounds in $\mathrm{CH}_{3} \mathrm{CN} .1$ continuous line, 2 dashed line.

The generation of ${ }^{1} \mathrm{O}_{2}$ upon irradiation was tested using a wellknown benchmark reaction like the oxygenation of 1,5dihydroxynaphthalene (DHN) to juglone, depicted in Scheme 2. ${ }^{18}$ Compounds 1 and $\mathbf{2}$ were irradiated in quartz cuvettes with light of $365 \mathrm{~nm}$. The analysis of the reaction was performed by UV-vis absorption measurements following the decreasing absorption of DHN at $298 \mathrm{~nm}$

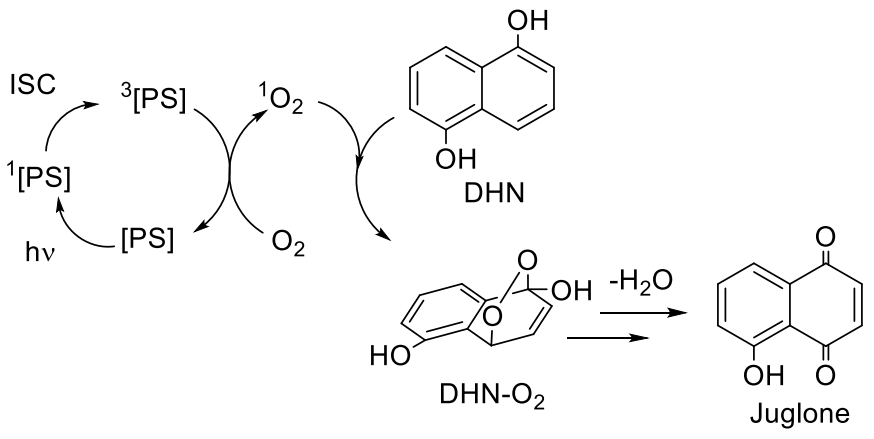

Scheme 2. Photooxidation reaction of DHN. PS = Acridine photosensitizer; ISC = Intersystem crossing; DHN = 1,5-dihydroxynaphthalene.

An illustrative example of the spectral changes occurring upon irradiation of acridine derivatives in the presence of DHN can be found in Figure 3. As it can be seen, the absorption bands of DHN at $298 \mathrm{~nm}$ disappear when increasing the irradiation time and, concomitantly, the rise of a new absorption band takes place at 425 $\mathrm{nm}$ corresponding to the juglone photoproduct.

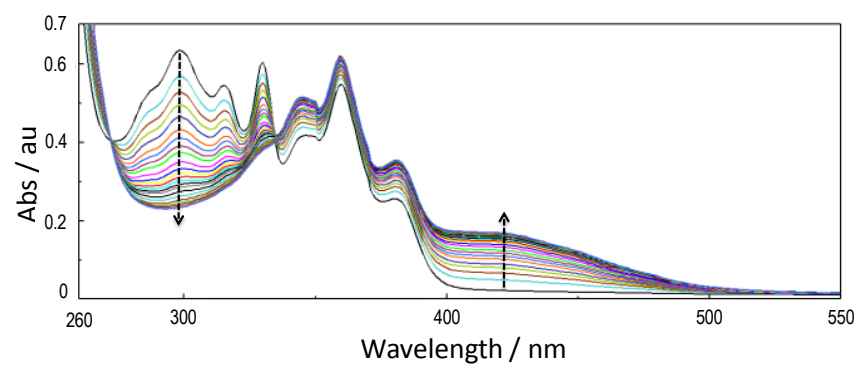

Figure 3. Photooxidation of DHN by ${ }^{1} \mathrm{O}_{2}$ induced by irradiation of $\mathbf{1}$ in $\mathrm{CH}_{3} \mathrm{CN}$, monitored by UV-Vis spectroscopy. [DHN] $=80 \mu \mathrm{M} ;[\mathbf{1}]=33 \mu \mathrm{M}$.

The initial kinetic points of the absorption bleaching of 1,5DHN were fitted to a pseudo-first order model $\left(\ln \mathrm{C} / \mathrm{C}_{0}=-\mathrm{k}_{\text {obs }} \cdot \mathrm{t}\right.$, where $\mathrm{C}$ is the concentration of $1,5-\mathrm{DHN}$ at a certain time $t$ and $\mathrm{C}_{0}$ is the initial concentration). The irradiations were performed in a series of media with different water content, from pure acetonitrile to pure water. The quantum yields for the singlet oxygen generation induced by irradiation of $\mathbf{1}$ and $\mathbf{2}$ were determined by comparing the slopes of the above mentioned fittings to the same reaction photosensitized by phenalenone, as a well-known photosensitizer standard $\left(\Phi_{\Delta} \sim 1\right),{ }^{19}$ in acetonitrile. All the fitted kinetics normalized to phenalenone can be visualized in Figure 4 (see details in the supporting information file). 


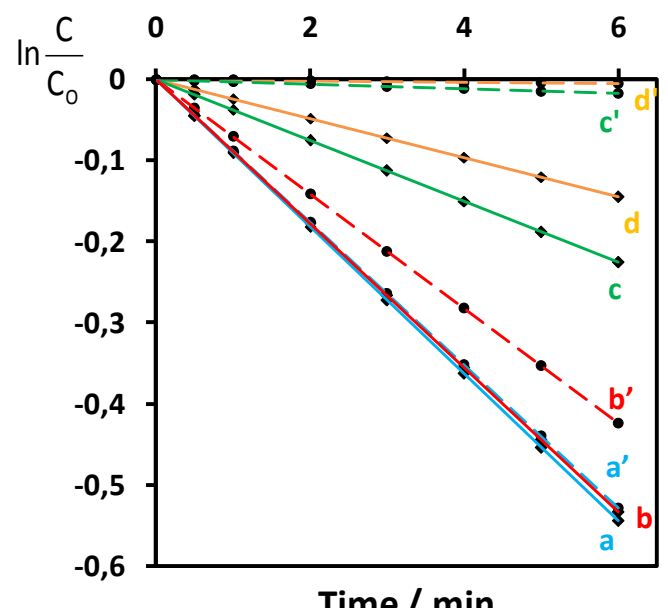

Time / min

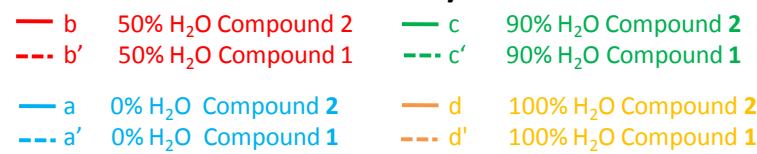

Figure 4. Comparison of pseudo-first order linear fitting for the production of singlet oxygen of $\mathbf{1}$ and $\mathbf{2}$ in different media $\left(\mathrm{CH}_{3} \mathrm{CN} / \mathrm{H}_{2} \mathrm{O}\right)$.

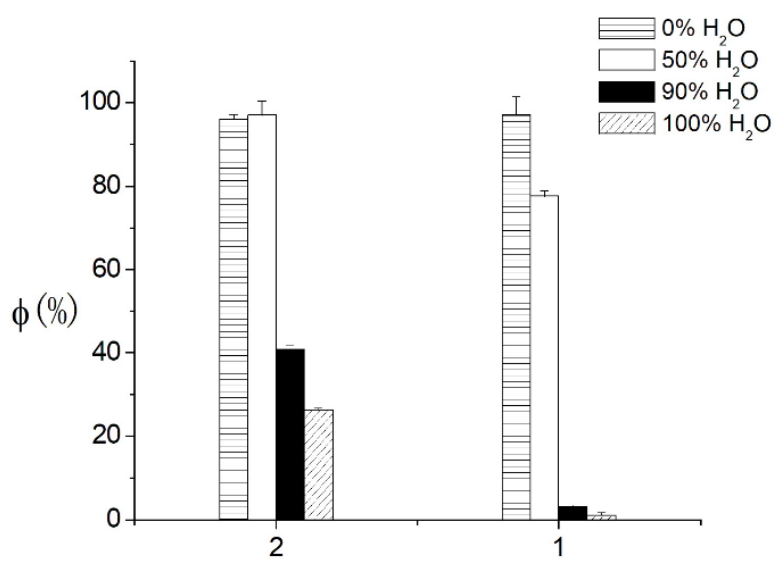

Figure 5. Singlet oxygen generation quantum yield $\left(\phi_{\Delta}\right)$ of compound $\mathbf{2}$ and $\mathbf{1}$ in different media $\left(\mathrm{CH}_{3} \mathrm{CN} / \mathrm{H}_{2} \mathrm{O}\right)$

As shown in Figure 5 both mono- (2) and bis-acridine (1) compounds generate very efficiently singlet oxygen upon irradiation at $365 \mathrm{~nm}$ in acetonitrile, as expected, with $\Phi_{\Delta}=0.97$ and 0.96 respectively. However, upon addition of water to the medium, this parameter falls dramatically, especially in the case of the bichromophoric compound $\mathbf{1}$ (in water $\Phi_{\Delta}=0.010$ ). However the decrease for monochromophoric derivative $\mathbf{2}$ is not so pronounced, affording a moderate yield $\left(\Phi_{\Delta}=0.263\right)$.

Table 1. Photochemical properties of compounds 1 and 2.

\begin{tabular}{cccccc}
\hline Compd. & Solvent & $\begin{array}{c}\lambda_{\text {abs }} \\
(\mathrm{nm})\end{array}$ & $\begin{array}{c}\lambda_{\text {em }} \\
(\mathrm{nm})\end{array}$ & $\Phi_{\mathrm{F}}$ & $\Phi_{\Delta}$ \\
\hline \multirow{2}{*}{$\mathbf{1}$} & $\mathrm{CH}_{3} \mathrm{CN}$ & 360 & 418 & $0.003 \pm 0.001$ & $0.96 \pm 0.04$ \\
& $\mathrm{H}_{2} \mathrm{O}^{\mathrm{a}}$ & 365 & 439 & $0.04 \pm 0.01$ & $0.010 \pm 0.008$ \\
\hline \multirow{2}{*}{$\mathbf{2}$} & $\mathrm{CH}_{3} \mathrm{CN}$ & 359 & 419 & $<0.001$ & $0.97 \pm 0.01$ \\
& $\mathrm{H}_{2} \mathrm{O}^{\mathrm{a}}$ & 357 & 435 & $0.32 \pm 0.06$ & $0.263 \pm 0.004$ \\
\hline
\end{tabular}

a: Contains $1 \% \mathrm{CH}_{3} \mathrm{CN}$ from a concentrated stock solution used to prepare the aqueous sample.

This differential behaviour prompted us to investigate the reason for the absence of photo-reactivity in the case of bichromophoric compound $\mathbf{1}$. Aqueous samples of $\mathbf{1}$ and $\mathbf{2}$ were analysed by dynamic light scattering (DLS) revealing a clear difference between them: whereas the larger compound $\mathbf{1}$ formed nanostructures in suspension with an average size of $122 \pm 11 \mathrm{~nm}$, monochromophoric acridine $\mathbf{2}$ did not form any detectable colloidal species (Figure 6(a)). Further experiments confirmed that 1 undergo self-aggregation in different polar and apolar solvents. Aggregates of bis-acridine compound $\mathbf{1}$ have been also observed by electron microscopy (SEM and TEM) with average sizes of 93 $\pm 24 \mathrm{~nm}$ and $135 \pm 40 \mathrm{~nm}$, respectively (Figure 6b-e).

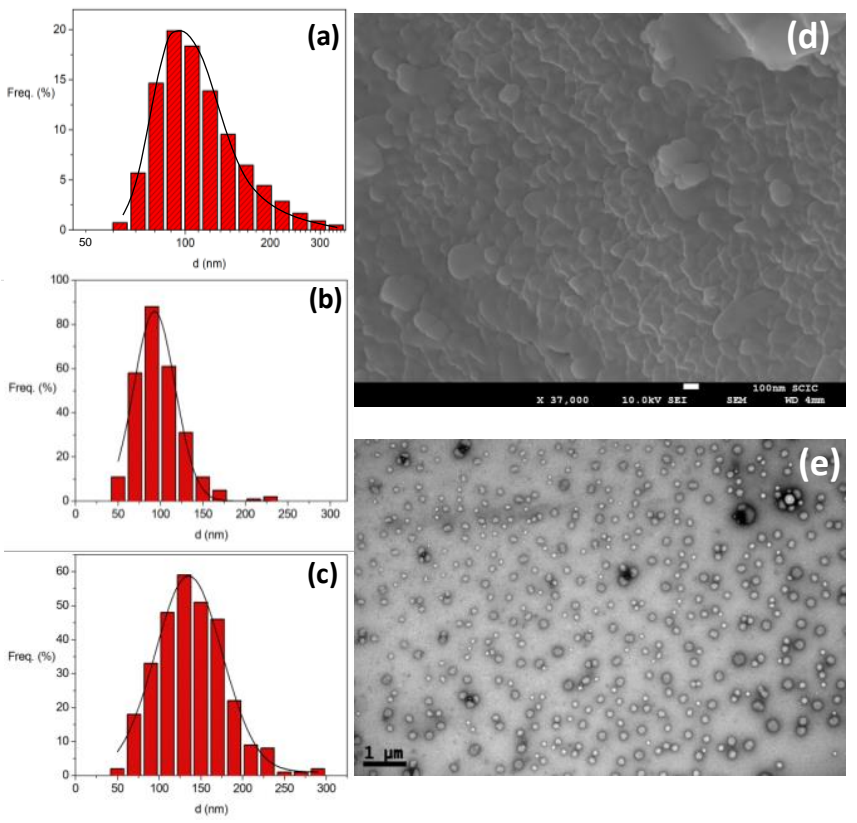

Figure 6. (a) Representative DLS analysis of 1 aggregates; (b) SEM analysis of 1 aggregates; (c) TEM analysis of 1 aggregates; (d) SEM micrograph of 1; (e) TEM micrograph of $\mathbf{1}$

This finding suggests that, upon aggregation, a competing pathway is favoured at the expense of energy transfer to triplet oxygen to yield ${ }^{1} \mathrm{O}_{2}$. This situation does not occur in the nonaggregated photosensitizer $\mathbf{2}$, which retains certain capacity to generate singlet oxygen in aqueous medium.

Compounds $\mathbf{1}$ and $\mathbf{2}$ have also very different properties from the photobiological viewpoint. When Hep3B cells incubated with the compounds were irradiated with light of $365 \mathrm{~nm}$, only 2 was capable of inducing some PDT effect. As it can be seen in Figure 7, Hep3B cells were incubated for $1 \mathrm{~h}$ in the presence of $2(10 \mu \mathrm{M})$ and then irradiated for $3 \mathrm{~min}$. Propidium iodide (PI) was used to test the photodamage, monitored by means of confocal fluorescence laser scanning microscopy (CLSM). Cells stained with PI after irradiations would indicate dead or damaged cells. In the control cells (no photosensitizer added) the number of damaged or dead cells was very low (only several per field) meaning that the irradiation per se was not deleterious. However, the number of PI-positive cells was dramatically increased in the cell population that was irradiated after up-take of $\mathbf{2}$, pointing to the existence of a particularly harmful effect on cell viability when the two stimuli $(2+$ irradiation $)$ were combined. The observed effect was confirmed by the quantitative assessment of PI fluorescence using fluorescence microscopy coupled with static cytometry (see supporting information). While the presence of $\mathbf{2}$ without irradiation only slightly enhances the number of $\mathrm{PI}^{+}$cells (3.38\% of the cells were PI positive after exposure to $20 \mu \mathrm{M} 2$ in comparison to $1.25 \%$ of the untreated cells), this number is notably higher when both stimuli are present and reaches the highest value with $20 \mu \mathrm{M}$ of $\mathbf{2}(8.7 \%)$. For compound 1, no induced photodamage was detected under the same experimental conditions. This observation confirms that aggregation must be avoided for photosensitizers based on acridine, at the designing stage, since this process hampers the generation of ${ }^{1} \mathrm{O}_{2}$. The negative effect of aggregation on the PDT activity is already well known for porphyrins and phthalocyanines, and efforts are 
devoted to the design of photosensitizers circumventing this process. ${ }^{20}$ According to the observations here reported, the same kind of considerations should be taken into account when dealing with acridine-based photosensitizers.

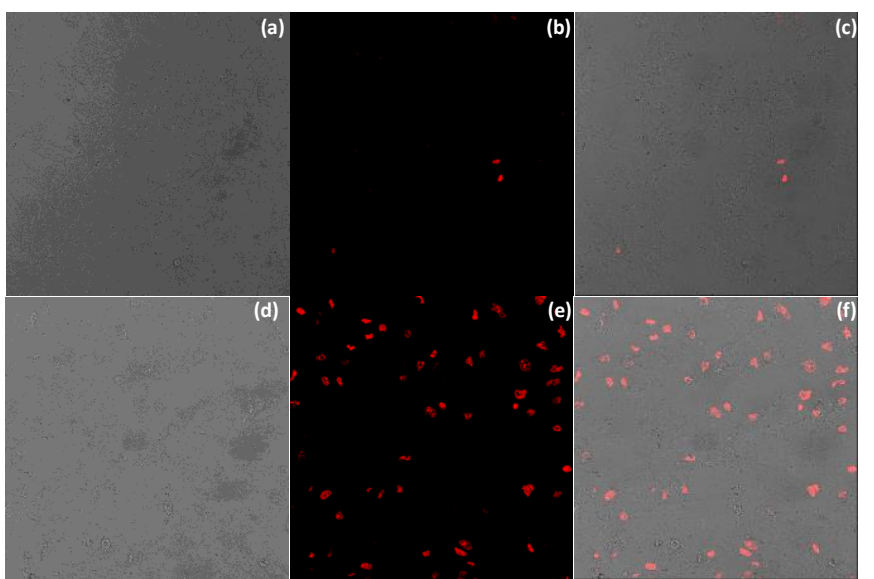

Figure 7. CLSM images of Hep3B cells (30.000 cell/well) stained with propidium iodide used to mark damaged or dead cells (visualized in red color) $(1 \mu \mathrm{M})$. Top row: Irradiated set of wells in absence of $2(10 \mu \mathrm{M})$; (a) bright field; (b) PI fluorescence, $\lambda_{\mathrm{ex}}=488 \mathrm{~nm}, \Delta \lambda_{\mathrm{em}}=500-700 \mathrm{~nm}$; (c) merged channels. Bottom row: Irradiated control set of wells in presence of 2; (d) bright field; (e) PI fluorescence, $\lambda_{\mathrm{ex}}=488 \mathrm{~nm}, \Delta \lambda_{\mathrm{em}}=500-700 \mathrm{~nm}$; (f) merged channels. Irradiation performed with UV lamp at $365 \mathrm{~nm}, 6 \mathrm{~W}$, for 3 minutes.

Despite the lack of PDT activity of $\mathbf{1}$, this compound retains the DNA binding ability. MTT (3-4,5-dimethylthiazol-2-yl-2,5diprenyl tetrazolium bromide) assays showed that exposure to $\mathbf{1}$ diminished cell viability in a concentration-dependent manner while exposure of $\mathbf{2}$ had no effect. The primary cell line Human umbilical vein endothelial cells (HUVEC) was slightly more susceptible than hepatoma cells Hep3B which is in line with previous reports of pharmacological toxicities using both cell models. ${ }^{21}$ After $3 \mathrm{~h}$ exposure to the highest concentration of $\mathbf{1}$ employed $(20 \mu \mathrm{M})$, the calculated $\mathrm{IC}_{50}$ was $29.5 \mu \mathrm{M}$ for Hep3B cells and $18.62 \mu \mathrm{M}$ for HUVEC. Of note, prolonged incubation $(24 \mathrm{~h})$ with 1 did not exacerbate the effect on cellular viability recorded after 3h-exposure, in Hep3B cells. In HUVEC cells, the prolonged incubation did have a greater effect (46\% and $27 \%$ vs control after $3 \mathrm{~h}$ - and $24 \mathrm{~h}$-incubation respectively). Also, we observed the capacity of both cell lines to recover from exposure to $\mathbf{1}$ and $\mathbf{2}$ ( $21 \mathrm{~h}$ recovery after the 3h-treatment, see Figure S4 in the supporting information file). The calculated $\mathrm{IC}_{50}$ value lies within the range of reported toxicities of similar compounds. Thus, Kožurková et al. described antitumor and binding studies of acridine dialkyldiureas in HeLa and HCT-116 cell lines with an $\mathrm{IC}_{50}$ of $3.1 \mu \mathrm{M} .{ }^{22}$ Analogously Arya et al. described several 9aminoacridine derivatives showing $\mathrm{IC}_{50}$ on the $5-10 \mu \mathrm{M}$ range in different cell lines; breast T47D, lung NCI-H522, colon HCT-15, ovary PA-1, liver HEPG2 and COS-1 cells. ${ }^{23}$ This fact could be related to the best binding ability of bichromphoric acridines as compared to the monochromophoric ones. ${ }^{6}$ Notably compound 2 is not toxic at concentrations lower than $20 \mu \mathrm{M}$.

The cellular uptake of compound $\mathbf{1}$ was examined by means of CLSM. As it can be seen in Figure 8, the uptake and subcellular localization of compound $\mathbf{1}$ was studied by live cell confocal fluorescence microscopy using Hep3B cells. These experiments revealed that after $1 \mathrm{~h}$ of incubation with $10 \mu \mathrm{M}$ of $\mathbf{1}$, fluorescence can be visualized inside cells and tend to localize in the perinuclear area, often in association with the nuclear membrane (Figure 8 inset). Specific co-localization experiments using organellespecific fluorochromes failed to show correlation of $\mathbf{1}$ with any of the subcellular compartments studied: ER, mitochondria and lysosomes (data not shown).
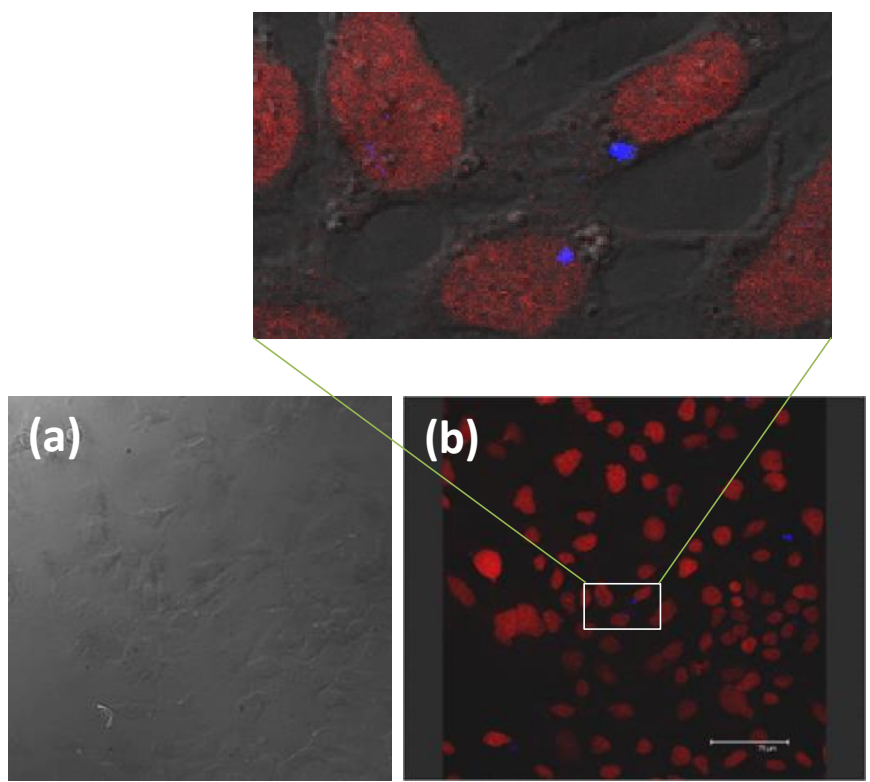

Figure 8. CLSM images of Hep3B cells (30.000 cell/well) of $1(10 \mu \mathrm{M})$ incubated for $1 \mathrm{~h}$ stained with Draq5 $(1 \mu \mathrm{M})$. (a) Bright field; (b) Merged images of Draq5 fluorescence (nuclei stained in red) and $\mathbf{1}$ fluorescence (blue) sequentially acquired (1 fluorescence, $\lambda_{\mathrm{ex}}=405 \mathrm{~nm}, \Delta \lambda_{\mathrm{em}}=410-550 \mathrm{~nm}$, Draq5 fluorescence, $\lambda_{\text {ex }}=488 \mathrm{~nm}, \Delta \lambda_{\text {em }}=600-700 \mathrm{~nm}$ ).

In summary, the synthesis and chemical characterization of two new acridine derived compounds, one monochromophoric (2) and the other bichromophoric (1), has been presented. Photophysical and photobiological studies of these compounds have been carried out. Their ability to produce singlet oxygen upon irradiation has been compared focusing the attention on the influence of chemical structure. The synthesized compounds show very different selfaggregating properties since only the bichromophoric molecule (1) presents a strong tendency to aggregate in water which blocks the ability to produce ${ }^{1} \mathrm{O}_{2}$. On the contrary, the non-aggregating molecule (2) still retains the ${ }^{1} \mathrm{O}_{2}$ production capacity, even in 100 $\%$ water $\left(\Phi_{\Delta}=0.263\right)$. In biological medium both compounds also show a distinct behaviour, probably due to their different selfaggregating properties. Thus, PDT studies were carried out with Hep3B cells which showed that only non-aggregated monochromophoric compound (2) has some efficiency after irradiation with UV light, probably due to production of singlet oxygen. Hence, it can be hypothesized that aggregation deactivate the excited states of the hydrophobic compound, discarding its use as a PDT agent. Nevertheless, despite of this lack of photoactivity, suspensions of this molecule, characterized as nano-sized aggregates, have notable antiproliferative activity, which opens the way for future studies on this class of compounds.

\section{Acknowledgments}

Ministerio de Economía y Competitividad of Spain (grant CTQ2015-71004-R) and Universitat Jaume I (grant P1.1B201576) are acknowledged for financial support. C.F.-L. thanks Ministerio de Economía y Competitividad of Spain for a FPI fellowship (CTQ2012-37735 and BES-2013-063296). Technical support from SCIC of University Jaume I is acknowledged.

\section{Supplementary Material}

Supplementary data associated with this article can be found in the online version.

\section{References and notes}

1. Wainwright M. J. Antimicrob. Ther. 2001, 47, 1. 
2. Cholewiński, G.; Dzierzbicka, K.; Kołodziejczyk, A. M. Pharmacol. Reports 2011, 63, 305

3. Denny, W. A. Curr. Med. Chem. 2002, 9, 1655; Belmont, P.; Bosson, J.; Godet, T.; Tiano, M. Anticancer. Agents Med. Chem. 2007, 7, 139.

4. Shinozuka, K.; Seto, Y.; Sawai, H.; Tuong, N. T.; Helene, C.; Makino, K. J. Chem. Soc. Chem. Commun. 1994, 23, 1377; Norman, T. J.; Parker, D.; Smith, F. C.; King, D. J. J. Chem. Soc., Chem. Commun. 1995, 0, 1879; Blagbrough, I. S.; Taylor, S.; Taylor, S.; Carpenter, M. L.; Novoselskiy, V.; Shamma, T.; Haworth, I. S. Chem. Commun. 1998, 18, 929; Li, L.; Kracht, J.; Peng, S.; Bernhardt, G.; Elz, S.; Buschauer, A. Bioorg. Med. Chem. Lett. 2003, 13, 1717; Takashima, H.; Tara, C.; Namikawa, S.; Kato, T.; Araki, Y.; Ito, O.; Tsukahara, K. J. Phys. Chem. B 2006, 110 , 26413; Farrera-Sinfreu, J.; Aviñó, A.; Navarro, I.; Aymamí, J.; Beteta, N. G.; Varón, S.; Pérez-Tomás, R.; Castillo-Avila, W.; Eritja, R.; Albericio, F.; Royo, M. Bioorg. Med. Chem. Lett. 2008 18, 2440; Janovec, L.; Kožurková, M.; Sabolová, D.; Ungvarský, J.; Paulíková, H.; Plšíková, J.; Vantová, Z.; Imrich, J. Bioorg. Med. Chem. 2011, 19, 1790.

5. Delcros, J. G.; Tomasi, S.; Carrington, S.; Martin, B.; Renault, J.; Blagbrough, I. S.; Uriac, P. J.Med.Chem. 2002, 45, 5098.

6. Far, S.; Kossanyi, A.; Verchère-Béaur, C.; Gresh, N.; Taillandier, E.; Perrée-Fauvet, M. J. Org. Chem. 2004, 1781; Borgions, F.; Ghyssels, D.; Van Aerschot, A.; Rozenski, J.; Herdewijn, P. Helv. Chim. Acta, 2006, 89, 1194.

7. Guetzoyan, L.; Ramiandrasoa, F.; Dorizon, H.; Desprez, C.; Bridoux, A.; Rogier, C.; Pradines, B.; Perrée-Fauvet, M. Bioorg. Med. Chem. Lett. 2007, 15, 3278.

8. Csuk, R.; Barthel, A.; Raschke, C.; Kluge, R.; Ströhl, D.; Trieschmann, L.; Böhm, G. Arch. Pharm. 2009, 342, 699.

9. Yang, P.; Yang, Q.; Qian, X.; Tong, L.; Li, X. J. Photochem. Photobiol. B, 2006, 84, 221; Benchabane, Y.; Di Giorgio, C.; Boyer, G.; Sabatier, A.-S.; Allegro, D.; Peyrot, V.; De Méo, M. Eur J. Med. Chem. 2009, 44, 2459; Satonaka, H.; Kusuzaki, K.; Matsubara, T.; Shintani, K.; Nakamura, T.; Matsumine, A.; Iino, T.; Uchida, A. Oncol. Lett. 2010, 1, 69; Pitchaimani, A.; Renganathan, A.; Cinthaikinian, S.; Premkumar, K. RSC Adv. 2014, 4, 22123; Čižeková, L.; Grolmusová, A.; Ipóthová, Z.; Barbieriková, Z.; Brezová, V.; Hunáková, L.; Imrich, J.; Janovec, L.; Dovinová, I.; Paulíková, H. Bioorg. Med. Chem. 2014, 22, 4684; Cisáriková, A.; Barbieriková, Z.; Janovec, L.; Imrich, J.; Hunáková, L.; Bačová, Z.; Paulíková, H. Bioorg. Med. Chem. 2016, 24, 2011; N. Mukherjee, N.; Podder, S.; Banerjee, S.; Majumdar, S.; Nandi, D.; Chakravarty, A. R. Eur. J. Med. Chem. 2016, 122, 497.

10. Iwamoto, Y.; Yoshioka, H.; Yanagihara, Y. Chem. Pharm. Bull. 1987, 35, 2478

11. Nonell S.; Flors C. Singlet oxygen: applications in biosciences and nanosciences, RSC, Cambridge, 2016; Ogilby P. R. Chem. Soc. Rev. 2010, 39, 3181; Huang, Y.-Y.; Sharma, S. K.; Dai, T.; Chung, H.; Yaroslavsky, A.; Garcia-Diaz, M.; Chang, J.; Chiang, L. Y.; Hamblin, M. R. Nanotechnol .Rev. 2012, 1, 111; Dolmans, D. E. J. G. J.; Fukumura, D.; Jain, R. K. Nature Reviews Cancer 2003, 3, 380; Macdonald, I. J.; Dougherty, T. J. J. Porphyrins and Phthalocyanines 2001, 5, 105; Galindo, F.; Kabir, N.; Gavrilovic, J.; Russell, D. a. Photochem. Photobiol. Sci. 2008, 7, 126; Beltrán, A.; Mikhailov, M.; Sokolov, M. N.; Pérez-Laguna, V.; Rezusta, A.; Revillo, M. J.; Galindo, F. J. Mater. Chem. B 2016, 4, 5975; FelipLeón, C.; Arnau del Valle, C.; Pérez-Laguna, V.; Isabel MillánLou, M.; Miravet, J. F.; Mikhailov, M.; Sokolov, M. N.; RezustaLópez, A.; Galindo, F. J. Mater. Chem. B 2017, 5, 6058.

12. Luan, L.; Ding, L.; Zhang, W.; Shi, J.; Yu, X.; Liu, W. Bioorg. Med. Chem. Lett. 2013, 23, 3775; Verwilst, P.; David, C. C.; Leen, V.; Hofkens, J.; de Witte, P. A. M.; De Borggraeve, W. M. Bioorg. Med. Chem. Lett. 2013, 23, 3204; Yanık, H.; Göksel, M.; Yeșilot, S.; Durmuş, M. Tetrahedron Lett. 2016, 57, 2922; , S.; Durmuş, M.; Bulut, M. Tetrahedron Lett. 2016, 57, 1124; Zhou, L.; Ge, X.; Liu, J.; Zhou, J.; Wei, S.; Li, F.; Shen, J. Bioorg. Med. Chem. Lett. 2013, 23, 5317; Li, X.-S.; Guo, J.; Zhuang, J.-J.; Zheng, B.-Y.; Ke, M.R.; Huang, J.-D. Bioorg. Med. Chem. Lett. 2015, 25, 2386; X. Guo, X.; Wang, L.; Wang, S.; Li, Y.; Zhang, F.; Song, B.; Zhao, W. Bioorg. Med. Chem. Lett. 2015, 25, 4078 Bio, M.; Rajaputra, P.; You, Y. Bioorg. Med. Chem. Lett. 2016, 26, 145; Slomp, A. M.; Barreira, S. M. W.; Carrenho, L. Z. B.; Vandresen, C. C.; Zattoni, I. F.; Ló, S. M. S.; Dallagnol, J. C. C.; Ducatti, D. R. B.; Orsato, A.; Duarte, M. E. R.; Noseda, M. D.; Otuki, M. F.; Gonçalves, A. G. Bioorg. Med. Chem. Lett. 2017, 27, 156.

13. Ghogare, A. A.; Greer, A. Chem. Rev. 2016, 116, 9994; Burguete, M. I.; Gavara, R.; Galindo, F.; Luis, S. V. Catal. Commun. 2010 11, 1081. Burguete, M. I.; Gavara, R.; Galindo, F.; Luis, S. V.
Tetrahedron Lett. 2010, 51, 3360. Fabregat, V.; Burguete, M. I.; Galindo, F.; Luis, S. V. Environ. Sci. Pollut. Res. 2014, 21, 11884. Fabregat, V.; Burguete, M. I.; Luis, S. V.; Galindo, F. RSC Adv. 2017, 7, 35154 .

14. O. Raab, Z. Biol. 1900, 39, 524.

15. Komorowski, S. J.; Grabowski, Z. R.; Zielenkiewicz, W. J. Photochem. 1985, 30, 141; Eberhard, J.; Peuntinger, K.; Rath, S.; Neumann, B.; Stammler, H.-G.; Guldi, D. M.; Mattay, J. Photochem. Photobiol. Sci. 2014, 13, 380.; Zhao, J.; Wu, W.; Sun, J.; Guo, S. Chem. Soc. Rev. 2013, 42, 5323.

16. Scurlock R. D.; Ogilby P. J. Photochem. Photobiol. A 1993, 72, 1.

17. Martí-Centelles, V.; Izquierdo, M. A.; Burguete, M. I.; Galindo, F.; Luis, S. V. Chem. - A Eur. J. 2014, 20 (24), 7465.

18. Takizawa S. Aboshi R. Murata S. Photochem. Photobiol. Sci. 2011, 10, 895; Wu, W.; Geng, Y.; Fan, W.; Li, Z.; Zhan, L.; Wu, X.; Zheng, J.; Zhao, J.; Wu, M. RSC Adv. 2014, 4, 51349

19. Schmidt, R.; Tanielian, C.; Dunsbach, R.; Wolff, C. J. Photochem. Photobiol. A Chem. 1994, 79, 11

20. Bennett, L. E.; Ghiggino, K. P.; Henderson, R. W. J. Photochem. Photobiol. B, 1989, 3, 81; Rossetti, F. C.; Lopes, L. B.; Carollo, A. R. H.; Thomazini, J. A.; Tedesco, A. C.; Bentley, M. V. L. B. J. Contr. Release 2011, 155, 400; Siraj, N.; Kolic, P. E.; Regmi, B. P.; Warner, I. M. Chem. Eur. J. 2015, 21, 14440.

21. Apostolova N, Gomez-Sucerquia LJ, Moran A, Alvarez A, BlasGarcia A, Esplugues J. V. J. Pharmacol. 2010, 160, 2069.

22. Kožurková, M.; Sabolová, D.; Janovec, L.; Mikeš, J.; Koval', J.; Ungvarský, J.; Štefanišinová, M.; Fedoročko, P.; Kristian, P.; Imrich, Bioorganic Med. Chem. 2008, 16, 3976-3984.

23. Arya, S.; Kumar, A.; Kumar, N.; Roy, P.; Sondhi, S. M. Med. Chem. Res. 2015, 24, 1942; Gensicka-Kowalewska, M.; Cholewí, G.; Dzierzbicka, K. RSC Adv. 2017, 7, 15776. 